\title{
Proces restrukturyzacji Zakładów Mięsnych "Nisko" S.A. jako potencjalny czynnik aktywizacji rolniczej bazy surowcowej północnej części województwa podkarpackiego
}

W warunkach przechodzenia do gospodarki rynkowej ważnym zagadnieniem badawczym jest problematyka funkcjonowania zakładów przemysłu rolno-spożywczego, będących elementem bardziej złożonej całości, jaką jest gospodarka żywnościowa. Przemysł rolno-spożywczy pozostaje $\mathrm{w}$ niej ważnym ogniwem integrującym produkcję rolniczą i konsumpcję. Wobec powszechności występowania przedsiębiorstw przemysłu spożywczego w strukturze przestrzennej gospodarki narodowej przemysł ten powinien być ważnym ogniwem wzrostu i modernizacji struktur regionalnych, zwłaszcza obszarów rolniczych. (Zioło 1991). W obrębie tego przemysłu istotne znaczenie ma branża mięsna, której wartość produkcji sprzedanej w 1998 r. stanowiła ok. $23 \%$ produkcji całego działu art. spożywczych i napojów oraz która zatrudniała ok. $25 \%$ osób pracujących w tym dziale przemyshu.

W świetle powyższych przesłanek przedmiotem rozważań będzie proces restrukturyzacji Zakładów Mięsnych „Nisko” S.A. na tle zmian w przemyśle mięsnym w Polsce. Podjęto próbę odpowiedzi na pytanie czy właściwie przeprowadzony proces przystosowania przedsiębiorstwa do reguł gospodarki rynkowej może być czynnikiem aktywizacji rolniczej produkcji zwierzęcej w północnej części województwa podkarpackiego i tym samym rozwoju całego, zagrożonego poważnymi problemami społeczno-gospodarczymi regionu (Rachwał 2000).

Zakłady Mięsne w Nisku, mają bogatą ponad 30-letnią tradycję. Decyzję o podjęciu budowy badanego przedsiębiorstwa podjęto na początku lat 60 . Podstawową przesłanką do podjęcia takiej decyzji było bogate zaplecze surowcowe regionu, nadwyżki kobiecej siły roboczej i jednocześnie brak dużego zakładu mięsnego $\mathrm{w}$ rozwijającym się regionie przemysłowym Stalowej Woli, odpowiadającego wzrastającym zapotrzebowaniom na przetwory mięsne. Zarządzeniem Ministra Przemysłu Spożywczego i Skupu utworzono w dn. 1 października 1968r. przedsiębiorstwo pod nazwą Zakłady Mięsne w Nisku. Zakres działania miał obejmować: ubój żywca, produkcję mięsa i przetworów mięsnych, sprzedaż hurtową mięsa, zbiórkę ubocznych artykułów poubojowych, produkcję mączek, kontraktację i skup zwierząt rzeźnych, sprzedaż detaliczną mięsa i jego przetworów w sklepach sieci własnej. Końcowy moment odbioru inwestycji i rozpoczęcie pełnej produkcji nastąpiło w lipcu 1969. Skup żywca dla potrzeb zakładu przewidziano na terenach powiatów: Niska, Tarnobrzega, Kolbuszowej i Leżajska. Pozostałe 50\% surowca miało być uzupełniane 
z rejonu działania Wojewódzkiego Przedsiębiorstwa Przemysłu Mięsnego w Lublinie. W zakresie zbytu zakładom wyznaczono zaopatrzenie 5 rejonów: Kolbuszowej, Leżajska, Niska, Stalowej Woli i Tamobrzega. Jednocześnie na pocz. lat 70. rozpoczęto produkcję eksportową m.in. do Stanów Zjednoczonych, Austrii, Włoch, Wielkiej Brytanii, RFN, Holandii, Finlandii, Grecji i Portugalii, a z krajów obozu socjalistycznego do ZSRR i Rumunii. Wraz ze zmianami administracyjnymi w 1975r. zaplecze surowcowe i zaopatrzenie zostało rozciągnięte na obszar nowoutworzonego województwa tarnobrzeskiego. Początek lat 80. w związku z panującym kryzysem gospodarczym, był bardzo trudny dla zakładów. Jednocześnie $w$ związku z brakami na rynku, rosło ich znaczenie i presja na zwiększenie produkcji. W tej sytuacji zakłady uruchamiały produkcję szeregu różnych tanich półmięsnych i lub mięsno-warzywnych produktów (jak bigos, gołąbki, fasolka po bretońsku). W celu przeciwdziałaniu problemom zaopatrzeniowym w surowiec zakłady rozpoczynaja własną hodowlę bydła, trzody i owiec. W trosce o poprawę zbytu rozpoczęto również zakładanie sklepów firmowych. Pierwsze z nich zostały uruchomione w 1981r. w Stalowej Woli. Lącznie w 1988r. zakłady posiadały 87 sklepów i bufetów, w tym kilka poza granicami województwa tarnobrzeskiego. W związku $\mathrm{z}$ rosnącymi mocami przerobowymi systematycznie inwestowano w technologię produkcji. Dalszy rozwój działalności rolniczej i hodowlanej nastąpił po przeprowadzonych w 1984r. zmianach organizacyjnych, polegających na przyporządkowaniu zakładom kilku mniejszych. Znaczne rozszerzenie działalności spowodowało zmianę nazwy na Wojewódzkie Przedsiębiorstwo Rolno-Przemysłowe w Nisku.

Zmiana systemu gospodarowania przyniosła całkowite usamodzielnienie się przedsiębiorstwa, które musiało samo w latach 90 . walczyć o utrzymanie pozycji konkurencyjnej na rynku. Pierwszą istotną zmianą były zmiany w strukturze organizacyjnej, polegające na oddzielenie się poszczególnych zakładów od przedsiębiorstwa. Z 7 kluczowych zakładów powołano w 1994 S.A. Zakłady Mięsne „Nisko”, która została włączona do programu NFI.

Ponieważ na początku procesu przemian gospodarczych w Polsce, w latach 19901993 przedsiębiorstwo nie przynosiło strat, kierownictwo nie dostrzegało potrzeby głębokich zmian funkcjonowania. Nie podjęto istotnych działań mających na usprawnienie zarządzania, modernizację linii technologicznych i tym samym obniżenia kosztów produkcji. Nie dokonano także istotnych zmian w asortymencie produkcji w celu dostosowania go do zmieniających się wymagań konsumentów. Brak efektywnego programu restrukturyzacji, w tym znalezienia środków na inwestycji w technologię produkcji doprowadził do sytuacji, w której przedsiębiorstwo systematycznie traciło w latach 90 . rynki zbytu. W efekcie w latach 1988-1999 nastappił znaczący spadek produkcji we wszystkich grupach asortymentowych (ryc.1.). np. szynki o $91 \%$, wędlin podrobowych o 79\%, thuszczy jadalnych o $82 \%$. Najmniejszy spadek nastapił w produkcji konserw (o 17\%), mączki paszowej (o 26\%) i wędlin pozostałych (o $29 \%$ ).

Duży wpływ na zmniejszenie produkcji miało załamanie się wschodnich rynków zbytu oraz utrata uprawnień do eksportu na rynki Unii Europejskiej. Konsekwencją konieczności ograniczenia produkcji był spadek skupu trzody o $54 \%$ i bydła o $57 \%$ (ryc.2.). Dodatkowe trudności w zaopatrzeniu związane były $\mathrm{z}$ nieterminowym regulowaniem należności i tym samym koniecznością ponoszenia wyższych kosztów zakupu w odległych regionach (nawet ponad $100 \mathrm{~km}$ ) lub korzystania z pomocy pośredników, którzy w związku z wysokim ryzykiem zawyżali swoje marże. Trudną sytuację pogłębił fakt nie przyznania dostaw półtusz z rezerw Agencji Rynku Rolnego, mimo iż Skarb Państwa posiada ok. 16\% akcji przedsiębiorstwa. 
Ryc.1 Zmiany wielkości produkcji Zakładów Mięsnych "Nisko"

wg ważniejszych grup asortymentowych w latach 1988-1999

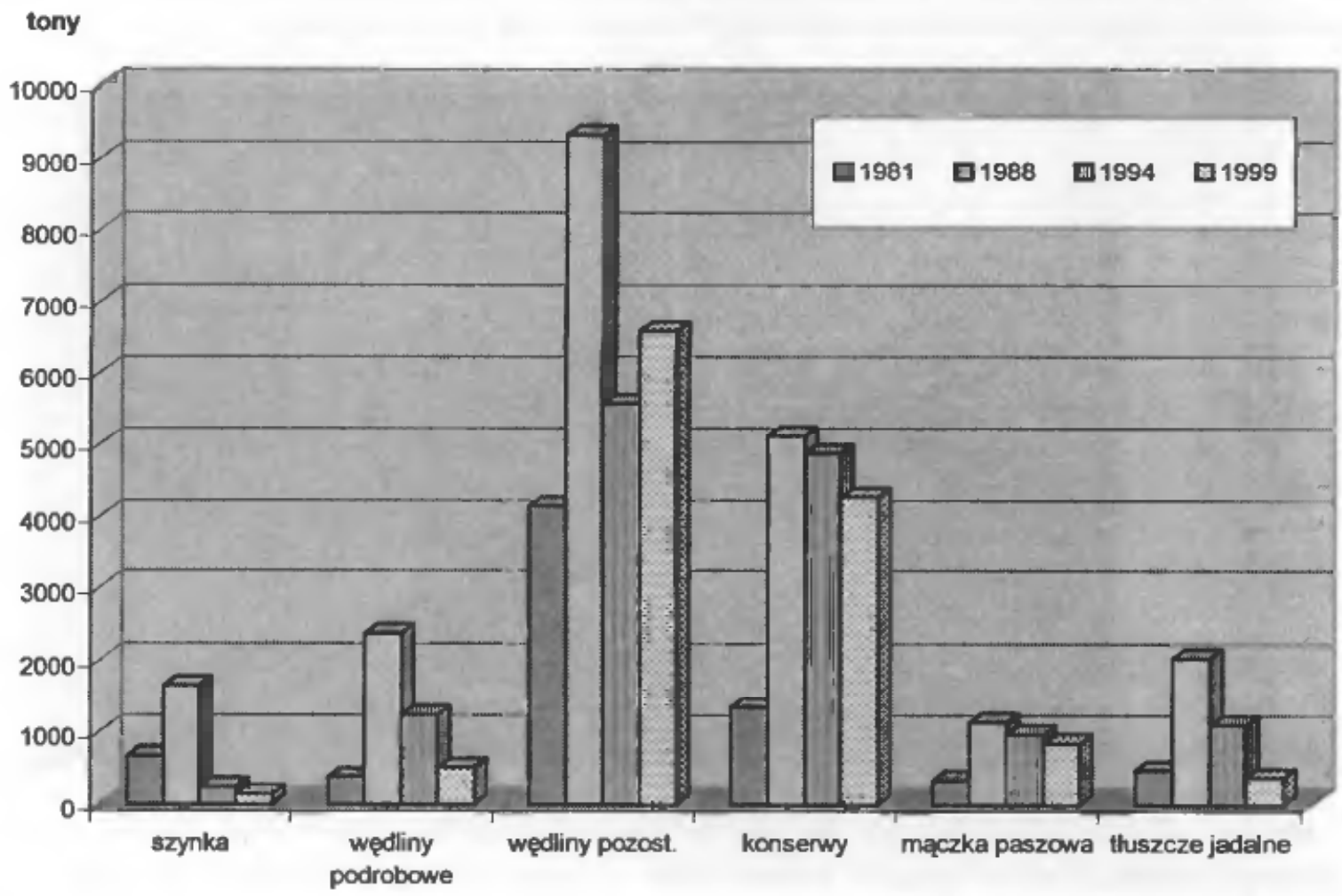

Ryc. 2 Skup trzody i bydła w Zakładach Mięsnych "Nisko" w latach 1981-1999

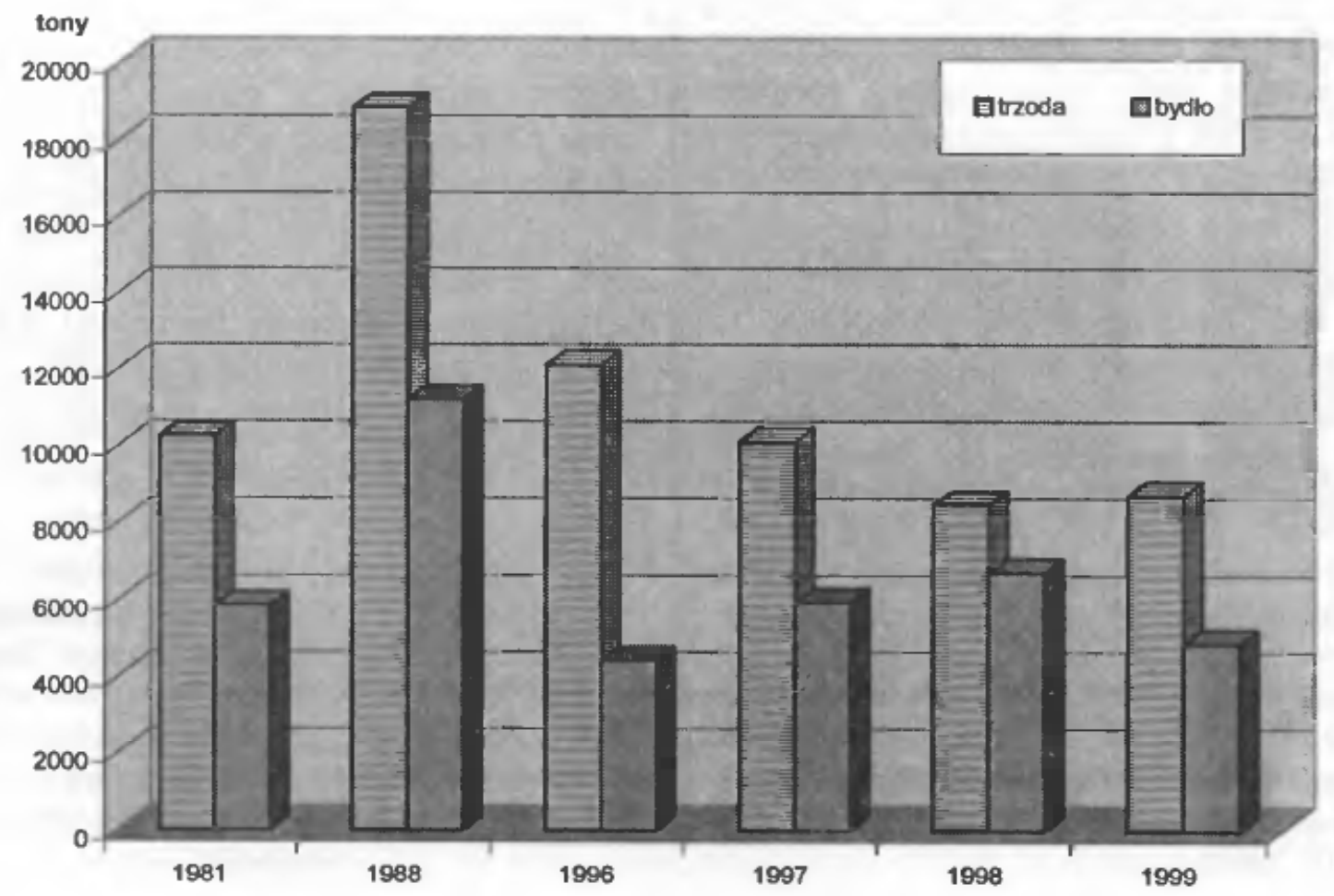


W celu obniżenia kosztów zmniejszeniu o $76 \%$ uległ także poziom zatrudnienia, z prawie 3700 osób zatrudnionych w 1988 r. do ok. 880 pod koniec 1999r. (ryc.3.). Niestety proces ten nie wiązał się $\mathbf{z}$ automatyzacją produkcji i eliminacją $\mathbf{w}$ niej pracy żywej, ale wynikał z prostego ograniczenia rozmiarów działalności produkcyjnej. Ryc. 3 Zmiany poziomu zatrudnienia w Zakładach Mięsnych "Nisko"
w latach 1988-1999

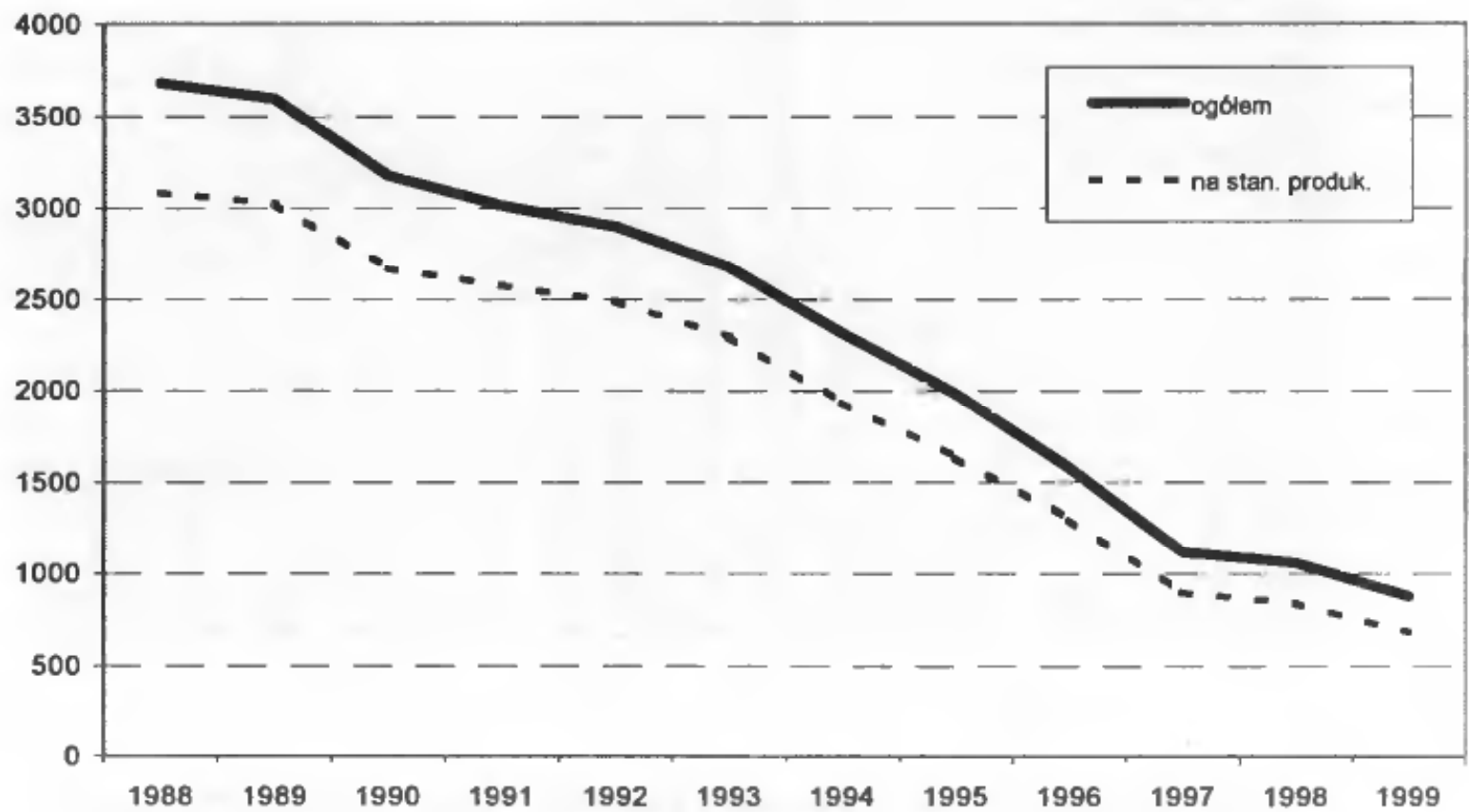

Mimo znacznej redukcji zatrudnienia przedsiębiorstwo przynosiło w latach 1993, 1995 i 1996 straty (ryc.4.) przedsiębiorstwo rozpoczęło więc poszukiwanie inwestora strategicznego, który opracowałby i sfinansowal proces naprawczy. W efekcie tych poszukiwań w 1999 r. większościowy udział objęła firma KERA Trading z Warszawy. Inwestor odkupując za 7,25 mln zl 60\% akcji od IV NFI Progress (i innych NFI, kontrolowanych przez Skarb Państwa i PZU) nie spełnił jednak oczekiwań zakładów, spłacił jedynie część długów i utrzymał przez rok poziom zatrudnienia, zgodnie z wynegocjowaną umową. Firma Kera Tradnig została założona w 1992 r., zajmuje się licznymi interesami, których większość dotyczy handlu z Rosją. Importuje aluminium, zajmuje się dostawami cukru, obsługuje spedycję oleju, eksportuje masę anodową i pak elektrodowy, handluje specjalistycznymi półproduktami z zakładów chemicznych, energią, gazem i mazutem. Dysponuje również biurem w Moskwie. ${ }^{1}$

' Firma ta była ściśle związana z Grzegorzem Żemkiem (do lutego 2001 prezes rady nadzorczej ZM „Nisko”), głównym oskarżonym w procesie Funduszu Obslugi Zadłużenia Zagranicznego. Grzegorz Żemek w marcu 2001 został aresztowany, postawiono mu m.in. zarzut wyłudzenia kredytów w banku PKO BP w Stalowej Woli, które posłużyły mu do zakupu Zakładów. Pogarszanie się sytuacji finansowej Zakładów było spowodowane m.in. wyprowadzaniem majątku (towaru i pieniędzy) do innych firm powiązanych z Grzegorzem Żemkiem (za „Rzeczpospolitą” z dn. 09.11.2000, 19.03.2001 i 30.03 .2001 ). 


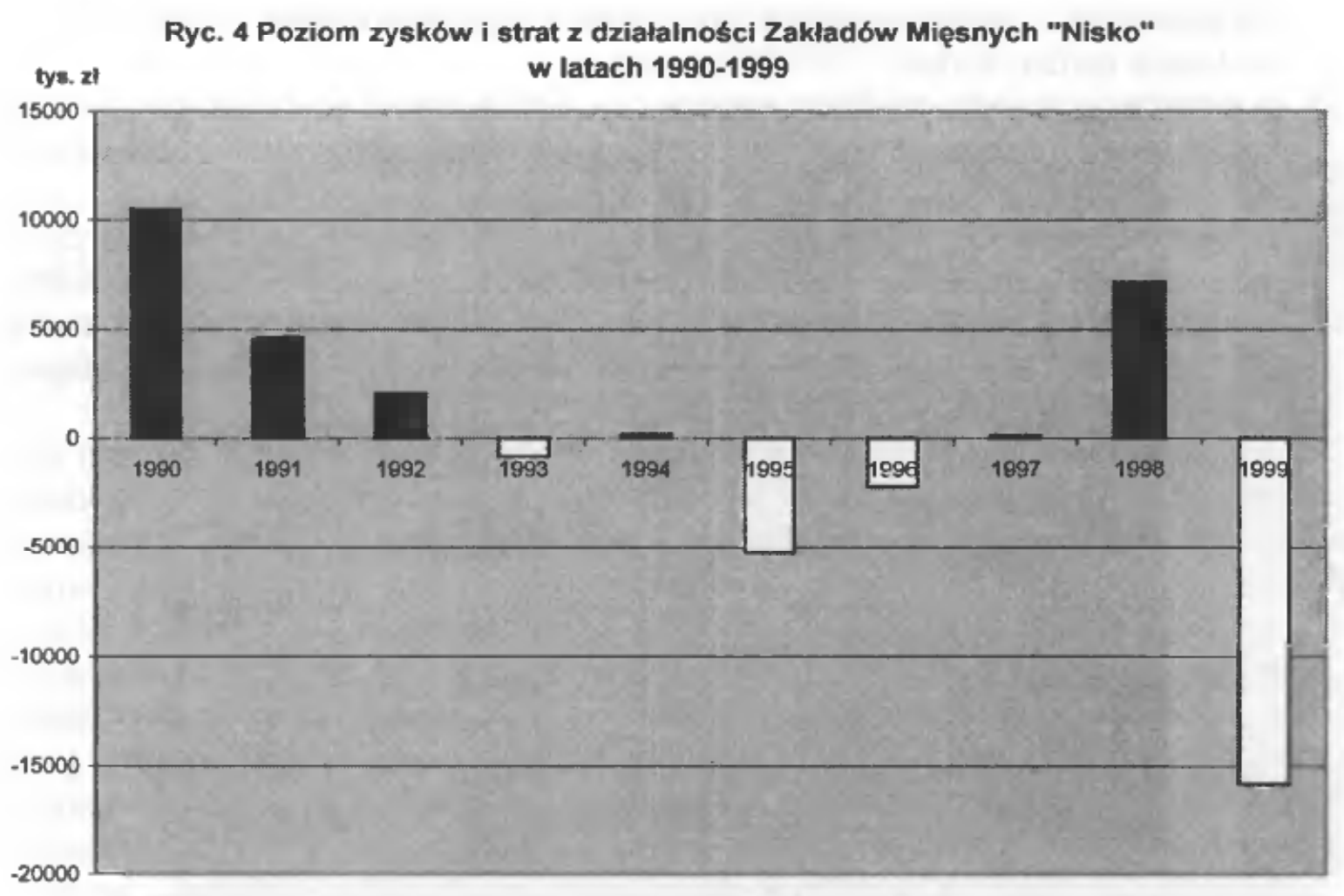

W ciagu pierwszego roku nie nastąpiły więc istotne zmiany w działalności przedsiębiorstwa. Program naprawczy nie jest wdrażany w życie, poziom produkcji coraz bardziej spada, konieczna będzie kolejna redukcja zatrudnienia (w 2000r. przewidywano zwolnienie 400 osób). Sytuacja w II poł. 2000r. w Zakładzie stała się dramatyczna, pracownikom nie wypłacono pensji, co wywołało strajk załogi wg szacunków długi firmy przekroczyły już $40 \mathrm{mln}$ zł. Przedsiębiorstwo jest uwikłane w procesy sądowe $\mathrm{z}$ dostawcami, którzy posądzają go o celowe wyłudzanie żywca do produkcji (ma ok. 1700 wierzycieli). Dodatkowo trudną sytuację potęgują ciągle zmiany we władzach spółki, w ciągu 18 miesięcy od sprywatyzowania spółki zarząd zmieniany był 10 razy. Zakład powoli traci więc nawet lokalne znaczenie i grozi mu postępowanie upadłościowe. Procesowi temu, mimo poparcia załogi, który tylko w ten sposób widzi możliwość otrzymania zaległych wynagrodzeń, sprzeciwia się jednak główny właściciel, firma Kera Trading².

Istnieje konieczność przystapienia do procesu natychmiastowej restrukturyzacji. Program naprawczy powinien obejmować przede wszystkim:

1) układy $\mathrm{z}$ wierzycielami - bankami oraz rolnikami w regionie. Zakłady mają problemy ze skupem surowca w najbliższej okolicy, gdyż producenci żądają uregulowania przeterminowanych (nawet 3-4 letnich) należności. Sytuacja ta doprowadziła do rezygnacji $z$ hodowli przez częśc gospodarstw, które dostarczały surowiec

${ }^{2}$ Sąd Gospodarczy w Tarnobrzegu 13 lutego 2001 r ogłosił upadłość Zakładów Mięsnych „Nisko" z powodu trwałego zaprzestania placenia długów. Syndyk rozpoczał prowadzenie rozmów z chętnymi na wydzierzawienie Zakładów. 
dla zakładów. Przerwanie ciągłości produkcji może spowodować, że jej odnowienie będzie bardzo trudne.

2) modernizację majątku produkcyjnego w celu dostosowania go do standardów Unii Europejskiej, działania te pozwolą na odbudowę utraconych rynków zachodnioeuropejskich oraz zmniejszenie kosztów produkcji.

3) zwiększenie aktywności marketingowej. Wyniki sprzedaży, prowadzonej przez spółkę DETAL sp. $z$ o.o. nie są zadowalające. Przedsiębiorstwo nie ma dobrze działającej sieci własnych sklepów czy stoisk firmowych, taj jak miało pod koniec lat 80 . (w efekcie w regionie własne sklepy/stoiska tworzą m.in. Zakłady Mięsne w Jarosławiu czy Beef-San z Sanoka/Przemyśla).

Uwzględniając aktualne tendencje w branży mięsnej przedsiębiorstwo powinno rozważyć kwestię fuzji z innymi zakładami w branży (tak jak to uczynił lokalny konkurent Zakłady Mięsne w Jarosławiu oraz inne wiodące przedsiębiorstwa w Polsce). Wydaje się, że tylko wejście poważnego inwestora branżowego może przyczynić się do rzeczywistej poprawy sytuacji przedsiębiorstwa. Tym bardziej, ze po załamaniu się rynku rosyjskiego sytuacja przemysłu mięsnego o 1998 i 1999r. znacznie się pogorszyła, tak że większość polskich przedsiębiorstw utraciła zdolność osiagania zysków. Średnioroczne wykorzystanie mocy produkcyjnych w ubojach ocenia się na ok. $40 \%$ a w przetwórstwie na $70 \%$. Poza tym dużym i średnim zakładom doskwiera, nieuczciwa ich zdaniem, konkurencja małych, prymitywnych ubojni, nie spełniających surowych warunków sanitarnych i często działających w szarej strefie. Najwięcej tego typu ubojni działa właśnie w południowej i wschodniej Polsce. Połączenie $\mathrm{z}$ innymi zakładami bądź włączenie się do już działających grup producenckich może istotnie wpłynąć na obniżenie kosztów produkcji i wzrost rentowności. Działania takie realizują m.in. Zakłady w Jarosławiu, Mięstar w Tarnowie, Sokołów i Farm Food w Czyżewie (woj. podlaskie), które utworzyły największą grupę przemysłu mięsnego w Polsce o możliwościach przerobowych 1000 ton mięsa dziennie. Dzięki samej tylko redukcji ówpokrywających się etatów (m.in. we władzach spółek), grupa ta planuje zaoszczędzić 5-7 mln złotych w 2000 r. Kolejne oszczędności ma przynieść lepsze wykorzystanie "połączonych" funduszy marketingowo-dystrybucyjnych oraz specjalizacja zakładów. Nad koniecznością takich posunięć zastanawiają się także inne przedsiębiorstwa. Proces konsolidacji jest opłacalny nawet dla przedsiębiorstw odległych od siebie, $\mathrm{z}$ różnych regionów Polski, tym bardziej więc celowe wydaje się łączenie przedsiębiorstw w grupy w oparciu o strukturę regionalną.

Dobrze funkcjonujące Zaklady w Nisku mogą stać się czynnikiem rozwoju rolnictwa w północnej części województwa podkarpackiego (oraz w niektórych gminach południowej części woj. lubelskiego i świętokrzyskiego) oraz poprawić pogarszającą się (w związku $\mathrm{z}$ upadkiem Zakładów Metalowych Nimet oraz redukcjami zatrudnienia w HSW) sytuację na lokalnym rynku pracy. Produkcja żywca rzeźnego w tym regionie wykazuje tendencję spadkową. W latach 1987-1997 w byłym woj. tarnobrzeskim spadek ten wyniósł w przypadku bydła prawie $60 \%$, cieląt i trzody blisko $25 \%$, natomiast owiec i koni praktycznie do zera (ryc. 5). 
Ryc. 5 Zmiany wielkości produkcji żywca rzeźnego w b. woj. tarnobrzeskim w latach 1987-1997

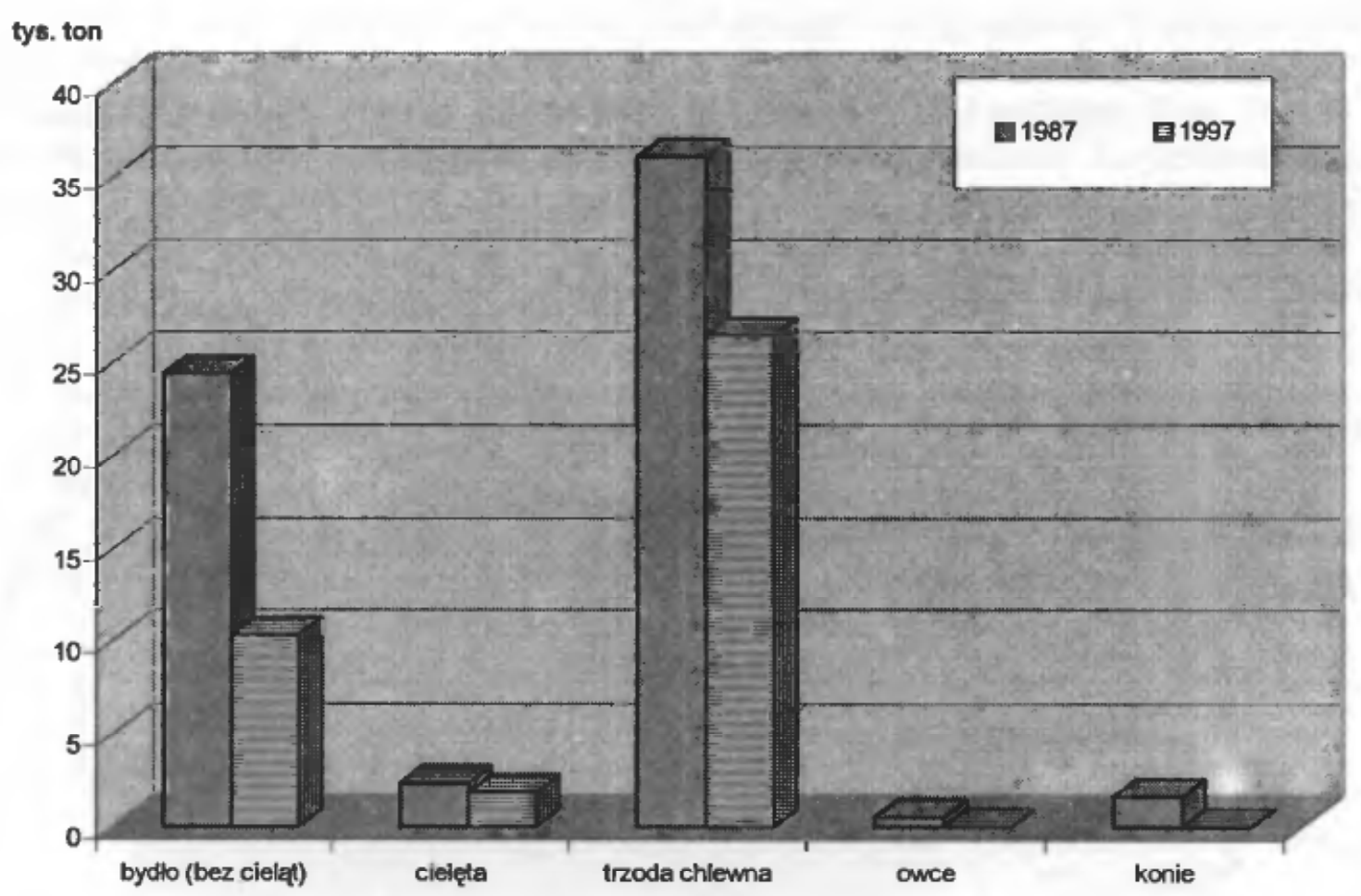

W kręgu potencjalnego zasięgu silnego oddziaływania zakładów w zakresie skupu znajduje się 5 powiatów: niżański, stalowowolski, tarnobrzeski, kolbuszowski, leżajski oraz znaczna część powiatów sandomierskiego, janowskiego, biłgorajskiego, łańcuckiego oraz rzeszowskiego (ryc. 6).

Szacunkowo można założyć, że przy wykorzystaniu pełnych mocy produkcyjnych zakładów produkcja żywca w tym rejonie mogłaby wzrosnąc do 80 tys. ton rocznie, tj. blisko dwukrotnie. Modernizacja linii technologicznych, powiązana $\mathrm{z}$ odzyskaniem praw eksportowych do UE i zwiększeniem mocy produkcyjnych, spowodowałaby objęcie słabszym zasięgiem oddziaływania kilkanaście kolejnych powiatów.

Podsumowując należy stwierdzić, że obecna sytuacja przedsiębiorstwa jest zła, przyczynił się do tego liczne błędy, w tym przede wszystkim zmiany własnościowe, najpierw bierne zachowanie Skarbu Państwa jak właściciela i bierne zarządzanie w czasie uczestnictwa w NFI, następnie wybór niewłaściwego inwestora strategicznego, firmy Kera trading. Nie dokonano zmian w strukturze zarządzania przedsiębiorstwem, nie obniżono istotnie kosztów produkcji, ograniczając się jedynie do redukcji zatrudnienia, nie podjęto działań mających na celu unowocześnienie majątku produkcyjnego i tym samym utrzymania praw eksportowych, oddano sieć sprzedaży detalicznej firmie, która nie gwarantuje zbytu produktów na odpowiednim poziomie. Warunkiem odbudowania przez Zakłady Mięsne w Nisku pozycji konkurencyjnej na rynku i aktywizacji produkcji rolnej w regionie są więc po pierwsze głębokie zmiany własnościowe. Wobec braku środków finansowych i nieja- 
snych deklaracji obecnego właściciela, konieczne wydaje się wejście nowego inwestora branżowego, który spłaci długi przedsiębiorstwa, odzyskując tym samym zaufanie dostawców i pracowników oraz rozpocznie inwestycje w środki produkcji i podejmie działania, mające na celu odzyskanie utraconych na rzecz konkurencji rynków zbytu. W przeciwnym razie przedsiębiorstwu grozi całkowita likwidacja. Wobec upadku kilku zakładów tej branży w woj. podkarpackim (m.in. Resmięs w Rzeszowie, zakłady drobiarskie) oraz braku innych, znaczących przedsiębiorstw $w$ tym regionie perspektywy dla rolniczej produkcji zwierzęcej nie są obiecujące.

Ryc. 6 Potencjalny obszar aktywizacji produkcji zwierzęcej

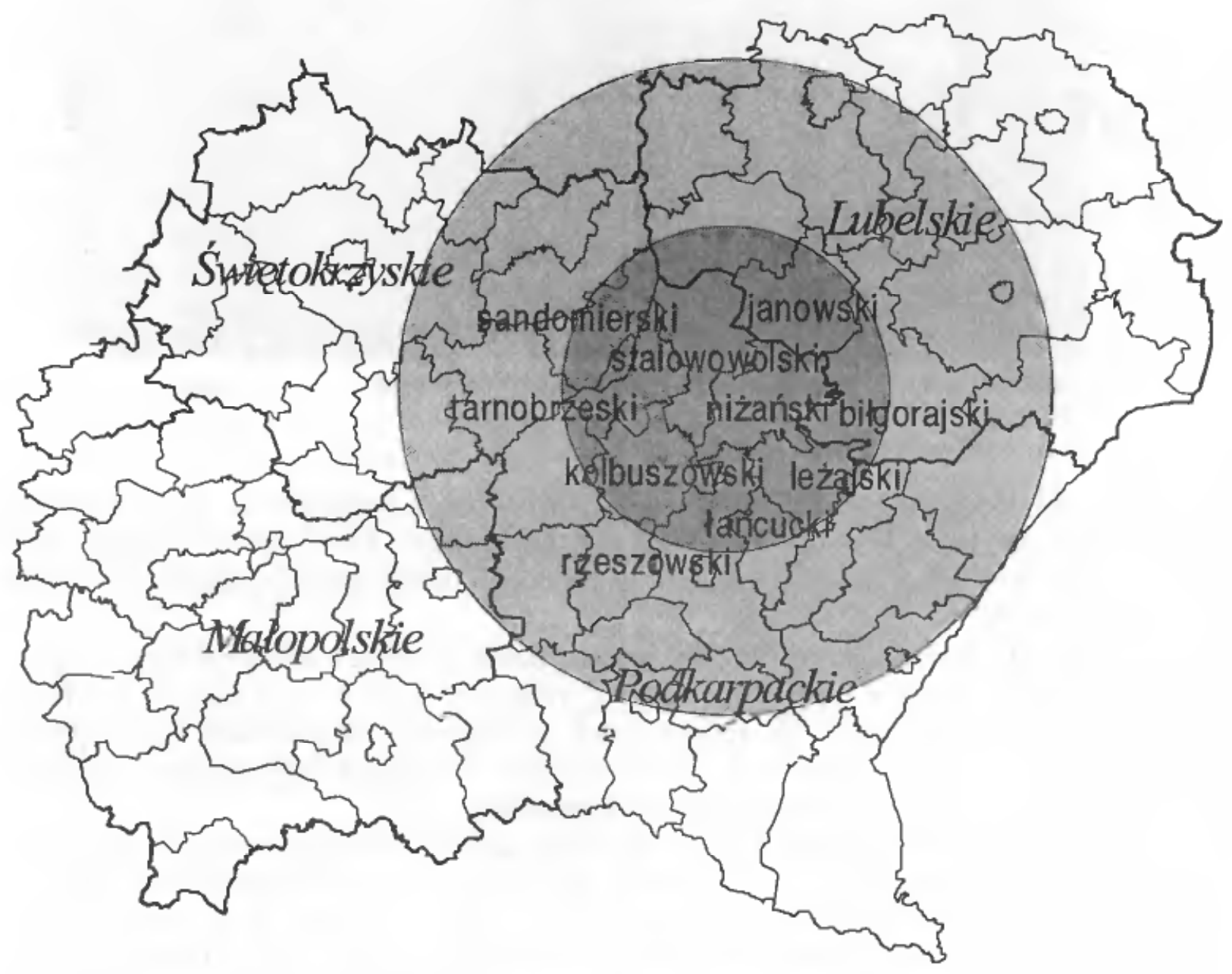

Obszar oddziaływania ZM Nisko na produkcję zwierzęca wg potencjalnych zasięgow skupu żywca
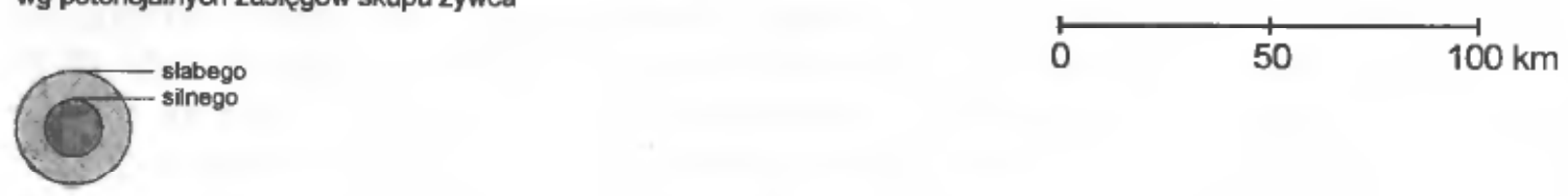


\section{Literatura}

Adamczak Z., 1994, Funkcjonowanie zakładów przemystu mięsnego w nowych warunkach społeczno-ekonomicznych (na przykładzie Zakładów Mięsnych w Krotoszynie) [w:] Funkcjonowanie przedsiębiorstw przemyslowych $w$ zmieniajqcych się warunkach gospodarowania, red. Z.Zioło, COMSN, KGP PTG, Kraków-Warszawa

Bis W., 1989, XX lat Zakładów Mięsnych w Nisku, Nisko

Rachwał T., 2000, Problematyka kwestionariusza do badań zmian funkcjonowania przedsiębiorstwa przemystowego $w$ procesie transformacji gospodarczej (w druku), Prace Komisji Geografii Przemysłu PTG, Kraków

Zioło Z., 1994, Zmiany otoczenia przedsiębiorstw przemystowych w nowych warunkach gospodarowania [w:] Funkcjonowanie przedsiębiorstw przemyslowych $w$ zmieniajacych się warunkach gospodarowania, red. Z.Zioło, COMSN, KGP PTG, KrakówWarszawa.

Zioło Z., 1991, Wprowadzenie [w:] Problemy przemyslu rolno-spożywczego $w$ badaniach geograficznych, red. Z.Zioło, COMSN, KGP PTG, Kraków-Warszawa 